\title{
ASPARTATE AND GLUTAMATE MODULATION OF GROWTH HORMONE SECRETION IN THE PIG: POSSIBLE SITE OF ACTION
}

\author{
C.R. Barb, R.M. Campbell, J.D. Armstrong, and N.M. Cox
}

\begin{abstract}
The influence of excitatory amino acids (EAA) on growth hormone (GH) secretion and the possible site of action was investigated in the pig. In Experiment (Exp) I three replicates were conducted with 30 prepuberal gilts, $130 \mathrm{~d}$ of age and averaging $70.6 \pm 1.3 \mathrm{~kg}$ body weight (BW). Six gilts each received intravenously (iv) $0,50,100$, or $150 \mathrm{mg} / \mathrm{kg} \mathrm{BW}$ of aspartate (ASP) or glutamate (GLU) in saline. Blood samples were collected every $15 \mathrm{~min}$ for $2 \mathrm{hr}$ before and $3 \mathrm{hr}$ after treatment. In Exp II, mature ovariectomized gilts (163 $\pm 10 \mathrm{~kg} \mathrm{BW})$ that had been immunized against growth hormone releasing factor (GRF) conjugated to human serum albumin (GRFi; $n=4$ ) or against human serum albumin alone (HSAi; $\mathrm{n}=5$ ) received $150 \mathrm{mg} / \mathrm{kg}$ BW ASP or GLU iv in a $2 \times 2$ factorial arrangement of treatments, which was then repeated in a crossover design. One week later, all animals received $10 \mathrm{mg} / \mathrm{kg} \mathrm{N}$-methyl-D,L-aspartate (NMA; EAA agonist) in saline iv. Blood samples were collected as described above. In Exp III, cultures of anterior pituitary cells from market-weight (averaging $105 \mathrm{~kg} \mathrm{BW})$ gilts were studied. On Day 4 of culture, cells $\left(10^{5} \mathrm{seeded} /\right.$ well) were challenged with $10^{-8}, 10^{-6}$, or $10^{-4} \mathrm{M}$ ASP or GLU, $10^{-6} \mathrm{M}\left[\mathrm{Ala}^{15}\right.$ ]-human GRF (1-29)- $\mathrm{NH}_{2}$, or the EAA antagonist, 2-amino-5-phosphonopentanoic acid (10 $0^{-4} \mathrm{M}$; AP5), alone or in combination with ASP or GLU. In Exp I, all doses of ASP and the 100- and 150-mg doses of GLU increased $(\mathrm{P}<0,05) \mathrm{GH}$ secretion when compared with Time 0 . However, serum GH concentrations were higher $(\mathrm{P}<0.01)$ after $150 \mathrm{mg} / \mathrm{kg}$ of ASP when compared with those after $150 \mathrm{mg} / \mathrm{kg}$ of GLU. In Exp II, serum GH concentrations increased $(\mathrm{P}<0.05)$ in HSAi but not in GRFi pigs (averaging $1.2 \pm 0.2 \mathrm{ng} / \mathrm{ml}$ before and $8.2 \pm 0.7,6.3 \pm 0.5$, and $9.2 \pm 0.5 \mathrm{ng} / \mathrm{ml}$ by $15 \mathrm{~min}$ after ASP, GLU, and NMA, respectively). In Exp III, relative to controls $(40 \pm 6 \mathrm{ng} / \mathrm{ml})$, GH increased $(\mathrm{P}<0.05) 1.6-$, 1.9-, and 1.9-fold and 1.7-, 1.8-, and 2.0-fold after $10^{-8}, 10^{-6}$, and $10^{-4} \mathrm{M}$ ASP and GLU, respectively. The EAA receptor antagonist AP5 failed to prevent the GH response to ASP or GLU, except for $10^{-8} \mathrm{M}$ ASP. In summary, ASP is a more potent secretagogue of GH secretion than is GLU in vivo, whereas each is equipotent in vitro. Because no stimulation of GH by EAA was observed in GRFi pigs and no specific dose-response effect of EAA was found in vitro, it may be concluded that modulation by EAA is mediated primarily at the level of the hypothalamus or higher brain centers.
\end{abstract}

\section{INTRODUCTION}

Excitatory amino acids (EAA), including glutamate (GLU) and aspartate (ASP), have been implicated as major neurotransmitters in the mammalian central nervous system (CNS) (1). Price et al. (2) demonstrated the preferential uptake of exogenously administered ASP and GLU by the circumventricular organs of the rat brain, including the arcuate nucleus. The systemic injection of GLU increased GLU levels fourfold in the median 
eminence, but not in other areas of the hypothalamus in mice (3). $\mathrm{N}$-Methyl-D,L-asparate (NMA), a potent agonist of ASP and GLU, stimulates the release of pituitary hormones, including luteinizing hormone (LH) (4-6) and growth hormone (GH) $(4,7,8)$. NMA stimulated GH secretion and accelerated growth in prepuberal monkeys (5) and dramatically increased serum concentrations of GH in wethers (7) and ovariectomized ewes (8). In the pig, NMA increased GH secretion without regard to steroid milieu (9). In contrast, the NMA stimulation of GH secretion from pig pituitary cells in vitro was influenced by the reproductive state of the pituitary donor (10). There is limited information on the influence of GLU and ASP on GH secretion in the pig. The objective of this study was to 1) determine the effect of GLU and ASP on GH secretion and 2) determine if the action of GLU and ASP appears to be directly on the pituitary and/or brain to modulate GH secretion.

\section{MATERIALS AND METHODS}

Experiment I. The experimental protocols were approved by the Institutional Animal Care and Use Committee. Fourteen prepuberal gilts (Yorkshire $\times$ Landrace $\times$ Hampshire), $130 \mathrm{~d}$ of age and averaging $70.6 \pm 1.3 \mathrm{~kg}$ body weight (BW), received 0 (control), 50,100, or $150 \mathrm{mg} / \mathrm{kg} \mathrm{BW}$ of $\mathrm{ASP}^{2}$ or $\mathrm{GLU}^{2}$ in saline intravenously (iv). One week later, the experiment was replicated with pigs reassigned to treatment such that no pig received the same dose as before, resulting in four pigs/dose of ASP, GLU, or saline. A third replicate was conducted with an additional 16 prepuberal gilts of the same genetic base, $130 \mathrm{~d}$ of age and averaging $70.1 \pm 1.1 \mathrm{~kg} \mathrm{BW}$. Two gilts each received either ASP or GLU at the doses described above, while four pigs acted as controls and received $0.9 \%$ saline iv. This resulted in six pigs/dose of ASP or GLU and eight control pigs across replicates. A cannula was placed in the jugular vein of all pigs the day before treatment. On the day of treatment, blood was collected every $15 \mathrm{~min}$ for $2 \mathrm{hr}$ before and $3 \mathrm{hr}$ after treatment. Serum was harvested and stored at $-20^{\circ} \mathrm{C}$ until assayed for $\mathrm{GH}$ by radioimmunoassay (RIA).

Experiment II. Mature ovariectomized pigs (Yorkshire $\times$ Hampshire; $163 \pm 10 \mathrm{~kg} \mathrm{BW}$ ) 10 to 12 months of age that had been immunized against growth hormone releasing factor (GRF) (1-29)-(Gly) $)_{4}$-Cys- $\mathrm{NH}_{2}$ conjugated to human serum albumin $(\mathrm{GRFi} ; \mathrm{n}=4$ ) or against human serum albumin alone (HSAi; $n=5$ ), as previously described (11), received $150 \mathrm{mg} / \mathrm{kg} \mathrm{BW}$ ASP or GLU iv in a $2 \times 2$ factorial arrangement of treatments, which was repeated $24 \mathrm{hr}$ later in a crossover design. One week later, all pigs were treated with NMA $(10 \mathrm{mg} / \mathrm{kg} \mathrm{BW})$ in saline iv. Blood samples were collected via a jugular vein cannula every $15 \mathrm{~min}$ for $2 \mathrm{hr}$ before and $3 \mathrm{hr}$ after treatment, and serum was handled as described in Exp I and assayed for GH. Antibody titers against GRF were determined as described below.

Experiment III. Two replicates were conducted with 12 and 6 pituitary glands per replicate, respectively. Pituitary glands were aseptically removed from cross-bred (Yorkshire $\times$ Landrace $\times$ Hampshire) gilts weighing approximately $105 \mathrm{~kg}$ and $180 \mathrm{~d}$ of age at slaughter. Ovaries were examined at slaughter, and gilts were considered prepuberal, because their ovaries were devoid of corpora albicantia and corpora lutea. All subsequent procedures were performed under sterile conditions. The anterior lobe was dissected from each pituitary gland, and cells were enzymatically dispersed and cultured as previously described $(12,13)$. To summarize the culture methods, after cells were dispersed and centrifuged, the cell pellet was resuspended in growth medium (Dulbecco's modified Eagle's medium [DME], Ham's nutrient mixture F-12 [F-12] $)^{2} 90 \%$ [vol/vol; 4,500 mg/l glucose], and $10 \%$ [vol/vol] Fitton-Jackson medium [BGjb] ${ }^{3}$ containing $2 \mathrm{mg} / \mathrm{ml}$ of bo- 
vine serum albumin, $10 \mathrm{mM} N$-hydroxyethylpiperazine- $N^{\prime}$-2-ethanesulfonic acid [pH 7.2], $100 \mathrm{U} / \mathrm{ml}$ of penicillin, $250 \mathrm{ng} / \mathrm{ml}$ of amphotericin B, ${ }^{2}$ and $100 \mu \mathrm{g} / \mathrm{ml}$ of streptomycin to which was added $2 \%$ [vol/vol] fetal bovine serum $),{ }^{2}$ which was supplemented with 100 $\mathrm{ng} / \mathrm{ml}$ of cortisol, $1.0 \mathrm{ng} / \mathrm{ml}$ of human insulin, $10 \mu \mathrm{g} / \mathrm{ml}$ of human transferrin, ${ }^{2} 10 \mathrm{pg} / \mathrm{ml}$ of glucagon, $100 \mathrm{pg} / \mathrm{ml}$ of human insulin, $10 \mu \mathrm{g} / \mathrm{ml}$ of human transferrin, ${ }^{2} 10 \mathrm{pg} / \mathrm{ml}$ of glucagon, $100 \mathrm{pg} / \mathrm{ml}$ of epidermal growth factor, $200 \mathrm{pg} / \mathrm{ml}$ of bovine parathyroid hormone, $400 \mathrm{pg} / \mathrm{ml}$ of triiodothyronine, ${ }^{2}$ and $200 \mathrm{pg} / \mathrm{ml}$ of fibroblast growth factor. ${ }^{4}$ Cell viability and number were assessed by counting the number of cells excluding trypan blue on a hemocytometer. Culture medium was changed on Day 3 (day of seeding $=$ Day 0 of culture) and replaced with serum-free growth medium as described before, except with DME containing $1,000 \mathrm{mg}$ of glucose $/ .^{2}$ On Day 4 of culture, medium was discarded, plates were rinsed twice with serum-free medium, and pituitary cells $\left(10^{5}\right.$ cells/well) were cultured in $1 \mathrm{ml}$ of fresh medium without serum. Cells were challenged with $10^{-6} \mathrm{M}$ synthetic GRF ([Ala $\left.{ }^{15}\right]$-hGRF(1-29)-NH $)^{5}$, ASP or GLU $\left(10^{-8}, 10^{-6}\right.$ or $\left.10^{-4} \mathrm{M}\right)$, or 2-amino-5-phosphonopentanoic acid (AP5; $10^{-4} \mathrm{M}$ ) alone or in combination with ASP or GLU. The dose of GRF and AP5 used was based on previous observations (10). Cells were exposed to treatment for $4 \mathrm{hr}$, at which time medium was harvested and quantified for $\mathrm{GH}$. There were three to seven wells per treatment per replicate.

Hormone Assays. Antibody titers against GRF were determined by incubating various dilutions of serum with $\left[{ }^{125} \mathrm{I}\right] \mathrm{GRF}(1-44)-\mathrm{NH}_{2}$. The antibody titer was expressed as the initial dilution of serum from GRFi gilts required to bind $30 \%\left[{ }^{125}\right.$ I]GRF or percent binding at a dilution of 1:100 in HSAi gilts. On Day $1,0.25 \mathrm{ml}$ of diluted serum, $0.15 \mathrm{ml}$ of assay buffer ( $0.1 \mathrm{M}$ acetate buffer; $\mathrm{pH} 5.6)$, and $0.1 \mathrm{ml}$ of [ $\left.{ }^{125} \mathrm{I}\right] \mathrm{GRF}$ ( 8,000 to 10,000 $\mathrm{cpm}$ in assay buffer) were aliquoted into glass $12 \times 75$ tubes, vortexed, and incubated for $24 \mathrm{hr}$ at $4^{\circ} \mathrm{C}$. Nonspecific binding was determined by incubating $0.4 \mathrm{ml}$ of assay buffer with $0.1 \mathrm{ml}$ of $\left[{ }^{125} \mathrm{I}\right] \mathrm{GRF}$. Nonspecific binding was less than $5 \%$. On Day $2,0.2 \mathrm{ml}$ of rabbit anti-pig gamma globulin (1:10 in assay buffer) and $0.5 \mathrm{ml}$ of $6 \%$ polyethyleneglycol in assay buffer were add to all tubes, mixed, and centrifuged at $2,000 \times g$ for $15 \mathrm{~min}$ to separate bound and free $\left[{ }^{125} \mathrm{I}\right] \mathrm{GRF}$. The supernatant was decanted, and the radioactivity in the remaining pellet was counted.

Radioiodination of GRF. An aliquot of $5 \mu \mathrm{g}$ of $\mathrm{GRF}^{2}$ in $5 \mu \mathrm{l}$ of $0.01 \mathrm{M}$ acetic acid was iodinated by the chloramine-T method (14). Ten microliters of $0.5 \mathrm{M}$ phosphate buffer ( $\mathrm{pH} 7.5$ ) was added to the reaction vial containing the GRF, and $10 \mu \mathrm{l}$ of $0.05 \mathrm{M}$ phosphate buffer ( $\mathrm{pH} 7.5$ ) was added to the vial containing $1 \mathrm{mCi}$ of $\left[{ }^{125} \mathrm{I}\right] \mathrm{Na}$, resulting in a total volume of $20 \mu \mathrm{l}$. One half of the $\left[{ }^{125} \mathrm{I}\right] \mathrm{Na}$ in $10 \mu \mathrm{I}$ was added to the reaction vial, and I $\mu \mathrm{g}$ of chloramine- $\mathrm{T}(1 \mu \mathrm{g} / 2 \mu \mathrm{l}$ of $0.05 \mathrm{M}$ phosphate buffer; $\mathrm{pH} 7.5)$ was mixed with GRF and $\left[{ }^{125} \mathrm{I}\right] \mathrm{Na}$ for $20 \mathrm{~s}$. The reaction was stopped with $2.5 \mu \mathrm{g}$ of sodium metabisulfate $(2.5$ $\mu \mathrm{g} / 5 \mu \mathrm{l}$ of $0.05 \mathrm{M}$ phosphate buffer; $\mathrm{pH} 7.5$ ) added to the reaction mixture for $30 \mathrm{~s}$. The reaction mixture was diluted with $100 \mu \mathrm{l}$ of $0.1 \%$ gelatin in $0.1 \mathrm{M}$ acetic acid and was layered on a $10 \times 1 \mathrm{~cm}$ Biogel P-4 $4^{6}$ column to separate free ${ }^{125}$ I from $\left[{ }^{125} \mathrm{I}\right] \mathrm{GRF}$.

Serum concentrations of GH were quantified by RIA (15). The assay sensitivity was 0.4 $\mathrm{ng} / \mathrm{ml}$. Intraassay and interassay coefficients of variation were $3.2 \%$ and $13.6 \%$, respectively.

Statistical Analysis. To determine the effect of ASP and GLU on GH secretion in Exp I, data were subjected to the general linear model split plot-in-time analysis of variance (ANOVA) procedure of the Statistical Analysis System (SAS; 16). The statistical model included amino acid, dose, pig, time, and replicate. The effects of amino acid, dose, amino acid $\times$ dose, and replicate were tested with replicate $\times$ amino acid $\times$ dose as the error term. Replicate $\times$ amino acid $\times$ dose was tested with pig within amino acid $\times$ dose $\times$ replicate 
as the error term. Time, time $\times$ amino acid, time $\times$ dose, and time $\times$ amino acid $\times$ dose were tested with amino acid $\times$ dose $\times$ time $\times$ replicate as the error term. Differences between treatment means within a time were determined by least-squares contrasts (16).

In Exp II, data were subjected to the general linear model split plot-in-time ANOVA (16). Data were analyzed with pig, treatment, and time as discrete (class) variables. Treatment was tested with animal within treatment as the error term. Time and treatment $x$ time were tested with the residual as the error term. If a significant treatment $\times$ time interaction was detected then differences between treatment means within a specific time were determined by least-squares contrasts (16).

In Exp III, data were converted to a percentage of basal secretion before averaging to minimize differences between replicates. To obtain an estimate of variation between control wells, medium $\mathrm{GH}$ concentrations for control wells were converted to a percentage of mean basal GH concentration. This was then used to calculate an SE for basal secretion. Basal secretion (control) was the amount of hormone secreted into the culture medium per $10^{5}$ cells seeded/well in the absence of a secretagogue. Converted data were tested for homogeneity of variance by the use of Hartley's $F_{\max }$ test (17). Data were pooled across replicates and then subjected to a one-way ANOVA (16). Differences between means were determined by least-squares contrast (16).

\section{RESULTS}

There were no amino acid $\times$ replicate $\times$ dose interactions detected in Exp I. Therefore, data were pooled across replicates. Amino acid $\times$ dose, amino acid $\times$ time, and dose $\times$ time $(\mathrm{P}<0.01)$ interactions were detected. Serum $\mathrm{GH}$ concentrations for each amino acid and dose are depicted in Figure 1. Four of the eight control animals exhibited an endogenous GH pulse at approximately $45 \mathrm{~min}$ after saline treatment. This accounted for the increase in GH secretion observed at this time for control pigs in Figure 1. Pretreatment serum GH concentrations were similar among groups. All of the ASP doses and the 100- and 150-mg doses of GLU increased $(\mathrm{P}<0.05) \mathrm{GH}$ secretion by $15 \mathrm{~min}$ after treatment when compared with the Time $0 \mathrm{GH}$ concentration (Figure 1). The peak $\mathrm{GH}$ response was higher (P $<0.01$ ) for the 100- and 150- mg doses of ASP when compared with the corresponding doses of GLU (Figure 2).

In Exp II, the antibody titer to GRF, expressed as percent binding at a dilution of $1: 10,000$, was $30.7 \pm 1.4 \%$ for GRFi pigs and was less than $5 \%$ for HSAi pigs when expressed as percent binding at a 1:100 dilution. Serum GH concentrations increased (P $<0.05$ ) only in HSAi pigs and averaged $1.2 \pm .2 \mathrm{ng} / \mathrm{ml}$ before and $8.2 \pm 0.7,6.3 \pm 0.5$, and $9.2 \pm 0.5 \mathrm{ng} / \mathrm{ml}$ by $15 \mathrm{~min}$ after $150 \mathrm{mg} / \mathrm{kg}$ ASP, GLU, or $10 \mathrm{mg} / \mathrm{kg}$ NMA, respectively (Figure 3$)$. In the NMA-treated pigs, a second increase $(P<0.05)$ in serum GH concentration was observed at $75 \mathrm{~min}$ after treatment (Figure 3 ). This most likely was due to a spontaneous $\mathrm{GH}$ pulse because $\mathrm{GH}$ concentrations returned to control levels by 45 min after NMA.

In Exp III, basal GH secretion by pituitary cells $\left(10^{5}\right.$ cells/well) was $40 \pm 6 \mathrm{ng} / \mathrm{ml}(\mathrm{n}=$ $14)$ and $\mathrm{GH}$ concentrations increased $(\mathrm{P}<0.05)$ threefold after $10^{-6} \mathrm{M}$ GRF compared with control (Figure 4). Relative to control, GH concentrations increased $(\mathrm{P}<0.05) 1.6$, 1.9, and 1.9-fold and 1.7, 1.8, and 2.0-fold after $10^{-8}, 10^{-6}$, and $10^{-4} \mathrm{M}$ ASP or GLU, respectively (Figure 4). The EAA receptor antagonist AP5 failed to prevent the GH response to ASP or GLU, except for $10^{-8} \mathrm{M}$ ASP (Figure 5).

\section{DISCUSSION}

The results of this study indicate that both ASP and GLU enhanced GH secretion in the prepuberal gilt, although ASP is a more potent secretagogue of GH secretion than GLU. 


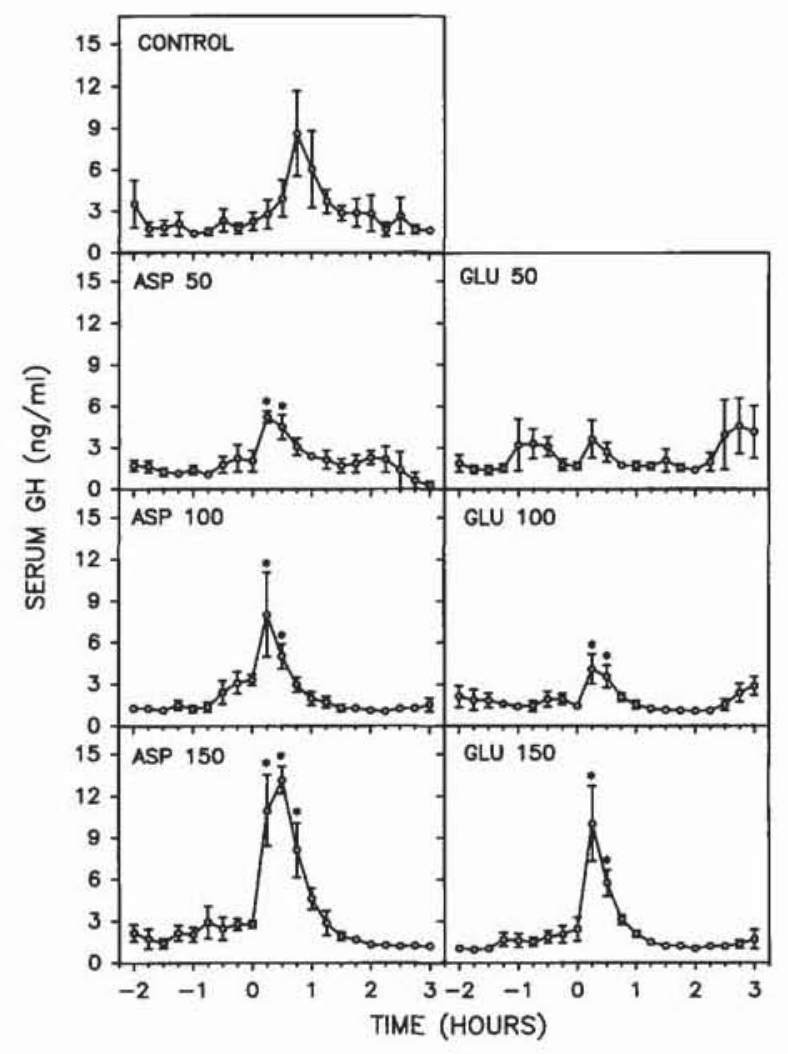

Figure 1. Serum GH concentrations (mean \pm SE) for pigs treated with 0 (control; $n=8) 50(n=6), 100(n=$ $6)$, or $150(n=6) \mathrm{mg} / \mathrm{kg} \mathrm{BW}$ ASP or GLU. Sample times at which significant effects of treatment were detected compared with Time 0 are indicated. ${ }^{*} \mathrm{P}<0.05$.

In Exp II, ASP, GLU, and NMA all stimulated GH secretion in mature ovariectomized gilts. We previously demonstrated that the systemic administration of NMA stimulated GH secretion in the mature gilt (9). Moreover, NMA stimulated GH secretion and accelerated growth in prepuberal monkeys (5) and dramatically increased concentrations of $\mathrm{GH}$ in gonadectomized male (7) and female (6) sheep. Further studies are now warranted to

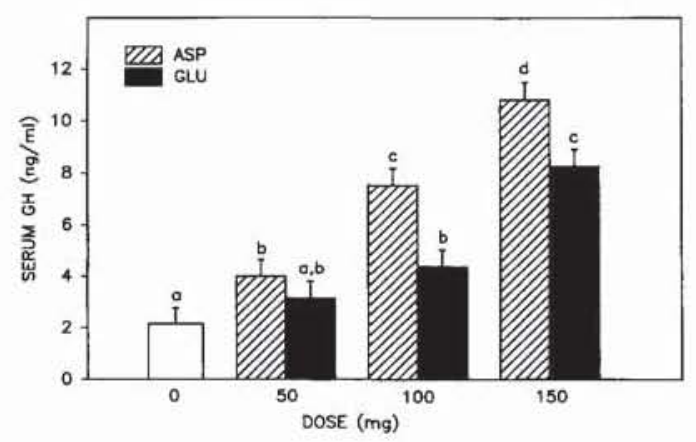

Figure 2. Mean ( \pm SE) serum GH concentrations by 15 min after treatment with saline $(0 ; n=8), 50(n=6), 100$ $(n=6)$, or $150 \mathrm{mg}(n=6) / \mathrm{kg} \mathrm{BW}$ of ASP or GLU. Columns with different letters differ $(P<0.01)$. 


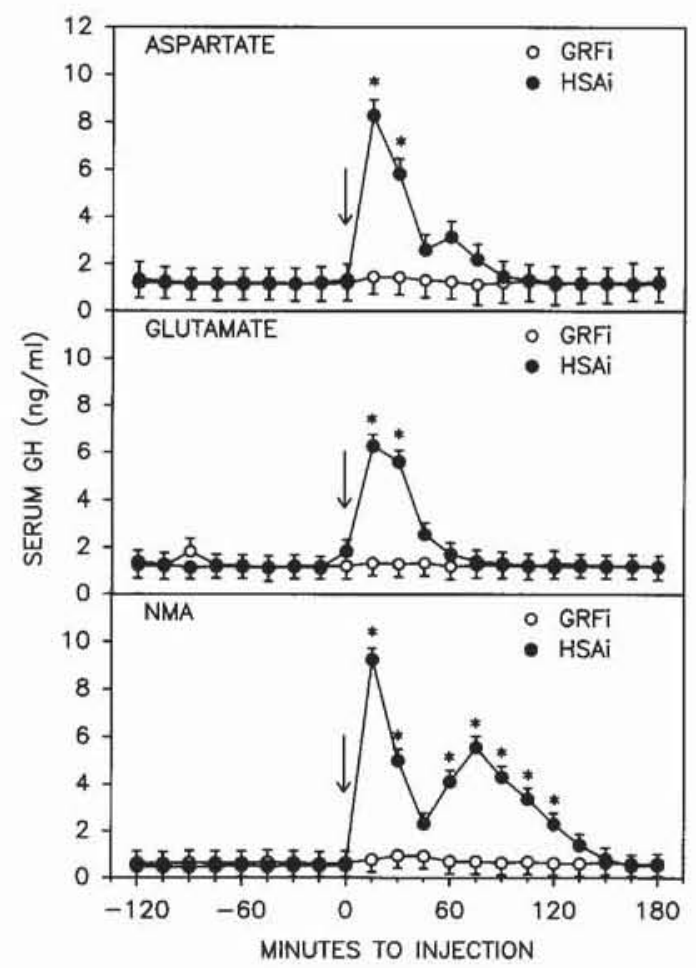

Figure 3. Serum GH concentrations (mean $\pm \mathrm{SE}$ ) before and after $150 \mathrm{mg} / \mathrm{kg} \mathrm{BW}$ of ASP, GLU or $10 \mathrm{mg} / \mathrm{kg}$ BW NMA (treatment $=$ Time 0$)$ for pigs immunized against GRFi $(n=4)$ or $\operatorname{HSAi}(n=5)$. Sample times at which significant effects of treatment were detected are indicated. $* \mathrm{P}<0.05$.

test whether the GH response is specific for each EAA and whether EAA plays a physiologic role in the control of $\mathrm{GH}$ secretion.

Acs et al. (18) reported that NMA failed to increase GH secretion when rats were pretreated with monosodium glutamate, which resulted in the destruction of hypothalamic neurons. Moreover, treatment with the NMA receptor antagonist MK-801 reduced hypothalamic GRF mRNA concentrations (19). The failure of exogenously administered EAA or NMA to increase GH secretion in pigs immunized against GRF supports the idea of a CNS site of action. Neural loci at which systemically administered EAA may act to affect $\mathrm{GH}$ release include the areas of the brain that lack a distinct blood-brain barrier. Price et al. (2) demonstrated the preferential uptake of exogenous ASP or GLU by the circumventricular organs of the rat brain, including the arcuate nucleus. The systemic injection of GLU increased GLU levels fourfold in the median eminence, but not in other areas of the hypothalamus in mice (3). Therefore, EAA might affect GH secretion by influencing GRF release from nerve terminals in the median eminence.

Alternatively, the immunoneutralization of GRF in this study may have altered the pituitary responsiveness to GRF secretion and the subsequent GH response to exogenously administered ASP, GLU, or NMA. In contrast, Klindt et al. (20) reported that viable somatotrophs were present after hypophyseal stalk transection in the pig in the absence of hypothalamic stimulatory input. Moreover, hypophyseal stalk-transacted gilts remained acutely responsive to GRF administration, exhibiting a twofold higher $\mathrm{GH}$ peak release than control animals (21). Therefore, it is likely that pituitaries of GRFi pigs remained responsive to GRF. 


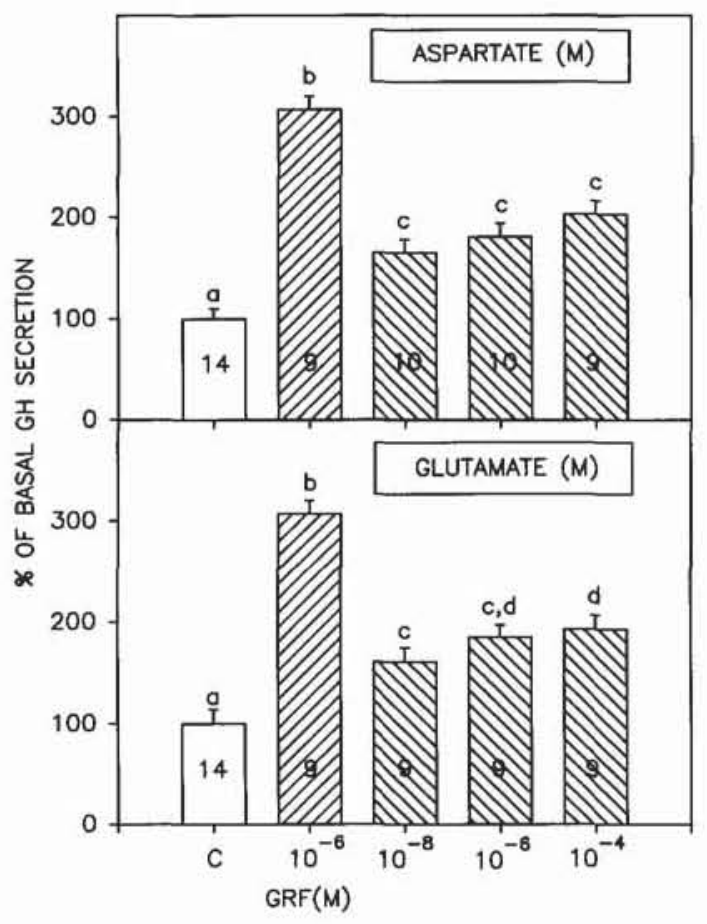

Figure 4. Effects of GRF, ASP, or GLU on GH secretion after $4 \mathrm{hr}$ of incubation. Values are mean $\pm \mathrm{SE}$. Number in column $=$ number of wells $\left(10^{5}\right.$ cells $/$ well $)$ per treatment. Basal secretion $(40 \pm 6 \mathrm{ng} / \mathrm{ml})=$ control $(C)$. Columns with different letters differ $(\mathrm{P}<0.05)$.

The influence of EAA on GH secretion was observed at all concentrations of the amino acids added to porcine pituitary cells in culture. A lack of a dose-dependent response to ASP and GLU and the failure of the EAA receptor antagonist AP5 to reverse stimulation by ASP and GLU on GH secretion suggest a possible nonspecific response rather than a response involving specific receptor activation. We previously reported that $10^{-4} \mathrm{M}$ AP5 failed to block the NMA-induced release of GH from pig pituitary cell in vitro, although this dose of AP5 antagonized the action of NMA on luteinizing hormone secretion (10). Therefore, it is possible that EAA receptors associated with GH secretion may not be antagonized by AP5 or the dose of AP5 used was insufficient to block the effects of ASP and GLU. Lindström and Ohlsson (22) reported that NMA stimulated GH secretion from isolated rat somatotrophs and that this effect was blocked by NMA receptor antagonists. In contrast, Acs et al. (18) and Cocilovo et al. (19) failed to demonstrate the stimulation of GH secretion from rat pituitary cells by NMA in culture. The apparent paradox between the in vivo and in vitro results in this study, together with previously published data, indicate that the EAA act at the level of the pituitary and CNS to modulate GH secretion. However, the results from Exp II suggest that the EAA act primarily at the level of the hypothalamus or higher brain centers to release GH, because the EAA-induced release of GH was blocked in GRFi gilts.

GLU and ASP not only act as neurotransmitters in the CNS, but also can be used in a more nonspecific way as amino acid substrates. Plasma concentrations of GLU and ASP normally range between 0.3 and $0.6 \mathrm{mM}$ and 0.03 and $0.1 \mathrm{mM}$, respectively (23). This is comparable to the concentrations of ASP and GLU used in this study. Blood concentrations of GLU and ASP can be altered by pathologic condition $(24,25)$, fasting, and diet 


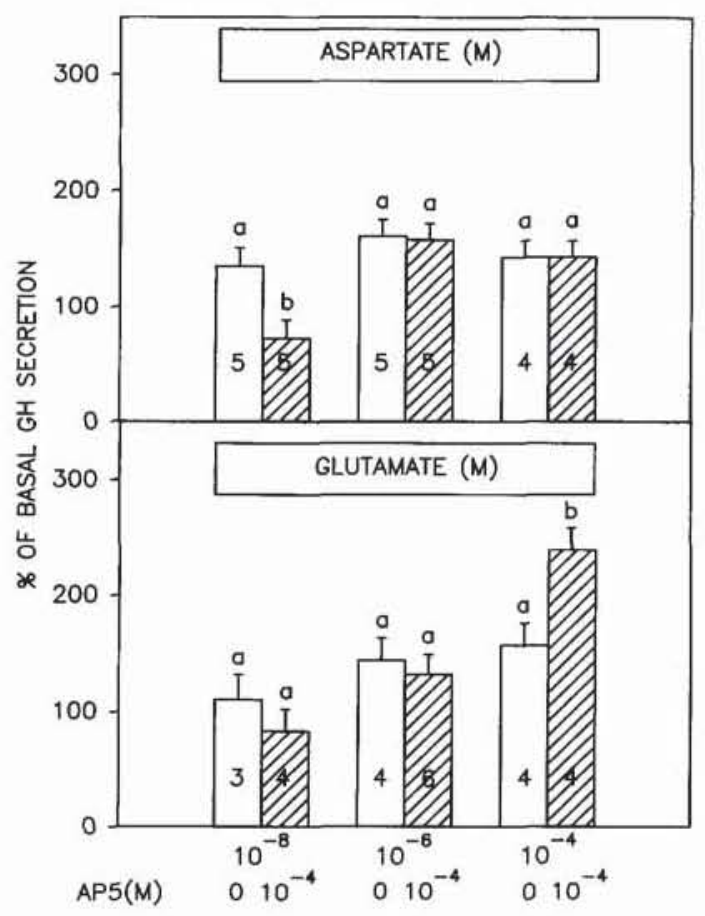

Figure 5. Effects of AP5 in combination with ASP or GLU on GH secretion after $4 \mathrm{hr}$ of incubation. Values are mean \pm SE. Number in column $=$ number of wells $\left(10^{5}\right.$ cells/well $)$ per treatment. Columns with different letters within a level of ASP or GLU differ from ASP or GLU + AP5 $(\mathrm{P}<0.05)$.

(23). It is conceivable that an alteration in the serum concentrations of these amino acids could influence GH secretion. In support of this idea, the median eminence, which contains fiber projections from GRF perikarya located in the median basal hypothalamus (26), and pituitary gland lie outside of the blood-brain barrier (27). Therefore, serum concentrations of GLU and/or ASP may influence hypothalamic GRF secretion, but also may have a direct effect on the pituitary gland.

In summary, ASP is a more potent secretagogue of GH secretion than GLU in vivo although each is equipotent in vitro. Because no stimulation of GH secretion by EAA was observed in GRFi pigs and no dose-response effect of EAA was found in vitro, it is concluded that the modulation of GH secretion by EAA is mediated primarily at the level of the hypothalamus or higher brain centers.

\section{ACKNOWLEDGMENTS/FOOTNOTES}

The authors thank Mr. John B. Barrett, Mr. Bennett Johnson, Mr. Russell Utley, and Ms. Elizabeth A. Taras for their technical assistance; Ruel L. Wilson, Biometrician, South Atlantic area, ARS, for his statistical advice; and Dr. A.F. Parlow, Harbor-UCLA Medical Center, Torrance, CA for providing the porcine GH antiserum AFP-1021854.

This research was supported by USDA funds and State and Hatch funds allocated to the Georgia Agricultural Experiment Station. The mention of a trade name, proprietary product, or Georgia Agricultural Experiment Station. The mention of a trade name, proprietary product, or specific equipment does not constitute a guarantee or warranty by the U.S. Department of Agriculture or the University of Georgia and does not imply its approval to the exclusion of other products that may be suitable.

'Corresponding author: Dr. C. Richard Barb, USDA, ARS, Animal Physiology, R.B. Russell Research Center, P.O. Box 5677, Athens, GA 30604-5677.

${ }^{2}$ Sigma Chemical Company, St. Louis, MO.

${ }^{3}$ Gibco, Grand Island, NY. 
${ }^{4}$ Collaborative Research, Bedford, MA.

${ }^{5}$ Hoffmann-LaRoche, Nutley, NJ.

${ }^{6}$ Bio-Rad, Richmond, CA.

\section{REFERENCES}

1. Watkins JC, Evans RH. Excitatory amino acid transmitters. Annu Rev Pharmacol Toxicol 21:165-204. 1981.

2. Price MT, Olney JW, Lowry OH, Buchsbaum S. Uptake of exogenous glutamate and aspartate by circumventricular organs but not other regions of brain. J Neurochem 36:1774-1780, 1981.

3. Perez VJ, Olney JW. Accumulation of glutamic acid in the arcuate nucleus of the hypothalamus of the infant mouse following subcutaneous administration of monosodium glutamate. J Neurochem 19:1777-1781, 1972.

4. Gay VL, Plant TM, N-methyl-d, 1-aspartate elicits hypothalamic gonadotropin-releasing hormone release in prepubertal male Rhesus monkeys (Macaca mulatta). Endocrinology 120:2289-2296, 1987.

5. Plant TM, Gay VL, Marshall GR, Arslan M. Puberty in monkeys is triggered by chemical stimulation of the hypothalamus. Proc Natl Acad Sci USA 86:2506-2510, 1989.

6. Estienne MJ, Schillo KK, Hileman SM, Green MA, Hayes SH. Effect of N-methyl-d, L-aspartate on luteinizing hormone secretion in ovariectomized ewes in the absence and presence of estradiol. Biol Reprod 42:126-130, 1990.

7. Estienne MJ, Schillo KK, Green MA, Hileman SM, Boling JA. N-methyl-d, 1-aspartate stimulates growth hormone but not luteinizing hormone secretion in the sheep. Life Sci 44:1527-1533, 1989.

8. Estienne MJ, Schillo KK, Green MA, Hileman SM. Growth hormone release after N-methyl-D, 1-aspartate in sheep: Dose response and effect of an opioid antagonist. J Anim Sci 68:3198-3202, 1990.

9. Barb CR, Derochers GM, Johnson B, Utley RV, Chang WJ, Rampecek GB, Kraeling RR. N-methyl-d, 1-aspartate stimulates growth hormone and prolactin but inhibits luteinizing hormone secretion in the pig. Domest Anim Endocrinol 9:225-232, 1992.

10. Barb CR. Barrett JB, Rampacek GB, Krealing RR. N-methyl-d 1-aspartate modulation of luteinizing hormone and growth hormone secretion from pig pituitary cells in culture. Life Sci 53:1157-1164, 1993.

11. Armstrong JD, Esbenshade KL, Johnson JL, Coffey MT, Heimer E, Campbell RM, Mowles T, Felix A. Active immunization of pigs against growth hormone-releasing factor: Effect on concentration of growth hormone and insulin-like growth factor. J Anim Sci 68:427-434, 1990.

12. Matteri RL, Becker BA, Lamberson WR, Somatotroph and lactotroph function in relation to grow in six-week-old pigs reared in a hot or cool environment. Domest Anim Endocrinol 11:101-114, 1994.

13. Barb CR, Kraeling RR, Rampacek GB. Glucose and free fatty acid modulation of growth hormone and luteinizing hormone secretion by cultured porcine pituitary cells. J Anim Sci 73:1416-1423, 1995.

14. Greenwood FC, Hunter WM, Glover JS. The preparation of 131 I-labeled human growth hormone of high specific radioactivity. Biochem J 80:114-123, 1963.

15. Barb CR, Estienne MJ, Kraeling RR, Marple DN, Rampacek GB, Rahe CH, Sartin JL. Endocrine changes in sows exposed to elevated ambient temperature during lactation. Domest Anim Endocrinol 8:117-127. 1991.

16. SAS. SAS User's Guide. Statistical Analysis of Systems Institute, Inc., Cary, NC, 1985.

17. Gill JL. Design and Analysis of Experiments in the Animal and Medical Sciences, Vol. 1. Iowa State University Press, Ames, 1978.

18. Acs Z, Lonart G. Makara GB. Role of hypothalamic factors (growth-hormone-releasing hormone and gamma-aminobutyric acid) in the regulation of growth hormone secretion in the neonatal and adult rat. Neuroendocrinology 52:156-160, 1990.

19. Cocilovo L, De Gennaro Colonna V, Zoli M, Biagini G, Settenbrini BP, Müller EE, Cocchi D. Central mechanisms suberving the impaired growth hormone secretion induced by persistent blockade of NMDA receptors in immature male rats. Neuroendocrinology 55:416-421, 1992.

20. Klindt J, Ford JJ, Berardinelli JG, Anderson LL. Growth hormone secretion after hypophysial stalk transection in pigs. Proc Soc Exp Biol Med 172:508-513, 1983.

21. Anderson LL, Ford JJ, Klindt J, Molina JR, Vale WW, Rivier J. Growth hormone and prolactin secretion in hypophysial stalk-transected pigs as affected by growth hormone and prolactin-releasing and inhibiting factors. Proc Soc Exp Biol Med 196:194-202, 1991.

22. Lindström P, Ohlsson L. Effect of n-methyl-d, 1-aspartate on isolated rat somatotrophs. Endocrinology 131:1903-1907, 1992.

23. Henry Y, Colleaux Y, Seve B. Effects of dietary level on lysine and of level and source of protein on feed 
intake, growth performance and plasma amino acid pattern in the finishing pig. J Anim Sci 70:188-195. 1992.

24. Perry TL, Krieger C, Hansen S, Eisen A. Amyotrophic lateral sclerosis: amino acid levels in plasma and cerebrospinal fluid. Ann Neurol 28:12-17, 1990.

25. Ferrari MD, Odink J, Bos KD, Mallessy MJA, Bruyn GW. Neuroexcitatory plasma amino acids are elevated in migraine. Neurology 40:1582-1586, 1990.

26. Leshin LS, Barb CR, Kiser TE, Rampacek GB, Kraeling RR. Growth hormone-releasing hormone and somatostatin neurons within the porcine and bovine hypothalamus. Neuroendocrinology 59:251-264, 1994.

27. Meisenberg G, Simmons WH. Peptides an the blood-brain barrier. Life Sci 32:2611-2623, 1983. 